\title{
Male germ cell expression of the PAS domain kinase PASKIN and its novel target eukaryotic translation elongation factor eEF1A1
}

Eckhardt, K ; Troger, J ; Reissmann, J ; Katschinski, D M ; Wagner, K F ; Stengel, P ; Paasch, U ; Hunziker, P ; Borter, E ; Barth, S ; Schlafli, P ; Spielmann, P ; Stiehl, D P ; Camenisch, G ; Wenger, R

\begin{abstract}
PASKIN links energy flux and protein synthesis in yeast, regulates glycogen synthesis in mammals, and has been implicated in glucose-stimulated insulin production in pancreatic beta-cells. Using newly generated monoclonal antibodies, PASKIN was localized in the nuclei of human testis germ cells and in the midpiece of human sperm tails. A speckle-like nuclear pattern was observed for endogenous PASKIN in HeLa cells in addition to its cytoplasmic localization. By yeast two-hybrid screening, we identified the multifunctional eukaryotic translation elongation factor eEF1A1 as a novel interaction partner of PASKIN. This interaction was mapped to the PAS A and kinase domains of PASKIN and to the C-terminus of eEF1A1 using mammalian two-hybrid and GST pull-down assays. Kinase assays, mass spectrometry and site-directed mutagenesis revealed PASKIN auto-phosphorylation as well as eEF1A1 target phosphorylation mainly but not exclusively at Thr432. Wild-type but not kinase-inactive PASKIN increased the in vitro translation of a reporter cRNA. Whereas eEF1A1 did not localize to the nucleus, it co-localizes with PASKIN to the cytoplasm of HeLa cells. The two proteins also showed a remarkably similar localization in the midpiece of the sperm tail. These data suggest regulation of eEF1A1 by PASKIN-dependent phosphorylation in somatic as well as in sperm cells.
\end{abstract}

DOI: https://doi.org/10.1159/000104169

Posted at the Zurich Open Repository and Archive, University of Zurich ZORA URL: https://doi.org/10.5167/uzh-1261

Journal Article

Published Version

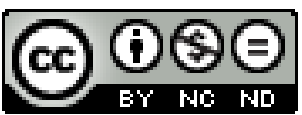

The following work is licensed under a Creative Commons: Attribution-NonCommercial-NoDerivatives 4.0 International (CC BY-NC-ND 4.0) License.

Originally published at:

Eckhardt, K; Troger, J; Reissmann, J; Katschinski, D M; Wagner, K F; Stengel, P; Paasch, U; Hunziker, P; Borter, E; Barth, S; Schlafli, P; Spielmann, P; Stiehl, D P; Camenisch, G; Wenger, R H (2007). Male germ cell expression of the PAS domain kinase PASKIN and its novel target eukaryotic translation elongation factor eEF1A1. Cellular Physiology and Biochemistry, 20(1-4):227-240.

DOI: https://doi.org/10.1159/000104169 


\title{
Cellular Physiology and Biochemistry
}

\section{Male Germ Cell Expression of the PAS Domain Kinase PASKIN and its Novel Target Eukaryotic Translation Elongation Factor eEF1A1}

\author{
Katrin Eckhardt,, 1,§,* Juliane Tröger, ${ }^{1, \S}$ Jana Reissmann, ${ }^{2}$ Dörthe M. \\ Katschinski, ${ }^{2,3}$ Klaus F. Wagner, ${ }^{4,5}$ Petra Stengel, ${ }^{4}$ Uwe Paasch, ${ }^{6}$ \\ Peter Hunziker, ${ }^{7}$ Emanuela Borter, ${ }^{1}$ Sandra Barth, ${ }^{1}$ Philipp Schläfli, ${ }^{1}$ \\ Patrick Spielmann, ${ }^{1}$ Daniel P. Stiehl, ${ }^{1}$ Gieri Camenisch ${ }^{1}$ and Roland \\ H. Wenger ${ }^{1}$
}

\begin{abstract}
${ }^{1}$ Institute of Physiology and Zürich Center for Integrative Human Physiology (ZIHP), University of Zürich, ${ }^{2}$ Cell Physiology Group, Medical Faculty, Martin-Luther-University Halle, ${ }^{3}$ Heart and Circulatory Physiology, Georg August University Göttingen, ${ }^{4}$ Institute of Physiology and ${ }^{5}$ Clinic of Anaesthesiology, University of Lübeck, ${ }^{6}$ European Training Center of Andrology, University of Leipzig, and ${ }^{7}$ Functional Genomics Center Zürich, University of Zürich, §The first two authors contributed equally to this publication, *Present address: Institute of Cell Biology, ETH Zürich
\end{abstract}

\section{Key Words}

Energy homeostasis • Glycogen synthesis • Nitrogen fixation $\cdot$ Protein phosphorylation $\cdot$ Protein translation - Testis

\begin{abstract}
PASKIN links energy flux and protein synthesis in yeast, regulates glycogen synthesis in mammals, and has been implicated in glucose-stimulated insulin production in pancreatic $\beta$-cells. Using newly generated monoclonal antibodies, PASKIN was localized in the nuclei of human testis germ cells and in the midpiece of human sperm tails. A speckle-like nuclear pattern was observed for endogenous PASKIN in HeLa cells in addition to its cytoplasmic localization. By yeast twohybrid screening, we identified the multifunctional
\end{abstract}

\section{KARGER}

Fax +41613061234

E-Mail karger@karger.ch

www.karger.com
(C) 2007 S. Karger AG, Basel

1015-8987/07/0204-0227\$23.50/0

Accessible online at:

www.karger.com/cpb eukaryotic translation elongation factor eEF1A1 as a novel interaction partner of PASKIN. This interaction was mapped to the PAS A and kinase domains of PASKIN and to the C-terminus of eEF1A1 using mammalian two-hybrid and GST pull-down assays. Kinase assays, mass spectrometry and site-directed mutagenesis revealed PASKIN auto-phosphorylation as well as eEF1A1 target phosphorylation mainly but not exclusively at Thr432. Wild-type but not kinase-inactive PASKIN increased the in vitro translation of a reporter cRNA. Whereas eEF1A1 did not localize to the nucleus, it co-localizes with PASKIN to the cytoplasm of HeLa cells. The two proteins also showed a remarkably similar localization in the midpiece of the sperm tail. These data suggest regulation of eEF1A1 by PASKIN-dependent phosphorylation in somatic as well as in sperm cells.

Copyright @ 2007 S. Karger AG, Base

\footnotetext{
R. H. Wenger

Institute of Physiology, University of Zürich

Winterthurerstrasse 190, CH-8057 Zürich (Switzerland)

Tel. +41 44 6355065, Fax +41446356814

E-Mail roland.wenger@access.uzh.ch
} 


\section{Introduction}

Physiological adaptations of an organism to changing environmental conditions require molecular sensors capable of sensing and signalling specific physicochemical parameters. The PAS (Per-Arnt-Sim) domain is a widespread protein fold of environmental protein sensors involved in the perception of light intensity, oxygen partial pressure, redox potentials, voltage and certain ligands [1]. In mammals, the PAS domain is mainly found as a heterodimerization interface of transcription factors involved in the molecular circadian clock, dioxin toxicity and oxygen sensing [2-4].

We and others previously identified a novel mammalian PAS protein, termed PASKIN [5] or PAS kinase [6]. The domain architecture of PASKIN resembles that of the oxygen sensor protein FixL from nitrogen-fixing Rhizobium species. PASKIN contains two PAS domains (PAS A and PAS B) and a serine/threonine kinase domain related to AMP kinases which might be regulated in cis by binding of so far unknown ligands to the PAS domain [7]. Following de-repression, autophosphorylation in trans results in the "switch-on" of the kinase domain of PASKIN [6]. The budding yeast PASKIN homologs PSK1 and PSK2 phosphorylate three translation factors and two enzymes involved in the regulation of glycogen and trehalose synthesis, thereby coordinately controlling translation and sugar flux [8]. Under stress conditions (nutrient restriction combined with high temperature), PASKIN kinase activity results in increased protein synthesis and decreased carbohydrate storage in yeast. PASKIN-dependent phosphorylation also inhibits the activity of the mammalian glycogen synthase [9]. In addition, a recent report suggested that PASKIN expression as well as kinase activity is increased in isolated pancreatic -cells following stimulation with high glucose levels [10]. Increased PASKIN activity appeared to be required for glucose-dependent transcriptional induction of preproinsulin gene expression, which might be related to PASKIN-dependent regulation of the nuclear import of pancreatic duodenal homeobox-1 transcription factor [11].

We recently generated PASKIN null mice by targeted replacement of the kinase domain of the mouse Paskin gene by a lacZ-neo fusion construct in embryonic stem cells $[12,13]$. Surprisingly, PASKIN expression is strongly upregulated in post-meiotic germ cells during spermatogenesis as revealed by in situ hybridization, galactosidase staining and mRNA blotting. In fact, PASKIN mRNA levels in testis are several magnitudes higher than in all other organs tested. However, at least under laboratory conditions, fertility as well as sperm production and sperm motility were not affected in PASKIN knock-out mice. No other organs, including pancreas, stained positive for galactosidase, and we could not detect any PASKIN-dependent insulin regulation [14].

To obtain more insights into PASKIN function, we generated specific monoclonal antibodies derived against PASKIN and screened a HeLa cDNA expression library in a yeast two-hybrid system to identify novel PASKIN interaction partners in mammals. Here we show that the eukaryotic translational elongation factor eEF1A1 interacts with PASKIN. eEF1A1 is a GTP-binding protein catalyzing the binding of charged aminoacyl-tRNA to the A-site of the ribosome [15-17]. eEF1A1 is of particular interest because it is related to the yeast translation initiation factor eIF1A that mediates the transfer of MettRNA to the 40S subunit of the ribosome, and which was shown to be regulated by the yeast PASKIN homologs PSK1 and PSK2 [8].

\section{Materials and Methods}

\section{Plasmids}

If not indicated otherwise, cloning work was carried out using Gateway technology (Invitrogen, Basel, Switzerland). pcDNA3hPASK [6], containing wild-type or mutant human PASKIN cDNA (kindly provided by J. Rutter, Salt Lake City, UT, USA), was digested with $\mathrm{Nco}$ I (all restriction enzymes were purchased from MBI Fermentas, Labforce, Nunningen, Switzerland), blunted with Klenow polymerase and subcloned into SalI-EcoRV-blunted pENTR4 (Invitrogen) to obtain pENTR4hPASK. The PAS domain plasmid pENTR4PAS was obtained by BamHI digestion and re-ligation of pENTR4hPASK. The kinase (KIN) domain plasmid pENTR4KIN was obtained by subcloning the Ecl136II fragment of pcDNA3hPASK into the XmnI-EcoRV sites of pENTR4. Other fragments of PASKIN were amplified by PCR using Pfu polymerase (MBI Fermentas), digested with NcoI and XhoI and subcloned into the same sites of pENTR4. The following primers (synthesized by Microsynth, Balgach, Switzerland) were used: PAS A (5'-cat gcc atg gta agt gtg tcc tgc tgc tcc ct-3' and $5^{\prime}$-cta get cga gtt act gcc gca tcc tct tca tcc-3'); PAS B (5'-cat gcc atg get tgg gtg ttc tgc acc atc-3' and $5^{\prime}$-cta get cga gtt agg cca ggt ctg gga gct gta-3'); N-terminal (5'-cag gac gcc cgc cat aaa ct-3' and 5'-cta get cga gtt atg agg acc acc ctg-3'); centerpiece (5'-cat gcc atg gag atc cga aag ctg atg gaa-3' and 5'-cta gct cga gtt act cag cag cgg tag agt gg-3'). pENTR4PASA1/2 was obtained by digesting pENTR4PASKIN with BamHI and HindIII, Klenow fill-in and re-ligation. The plasmid pCMV6XL5-eEF1A1, containing the full-length human eEF1A1 cDNA, was purchased from OriGene (Rockville, MD, USA). eEF1A1 was amplified by PCR (full-length: 5'-cat gcc atg gga aag gaa 
aag act cat atc-3' and 5'-cta get cga gcc gtt ctt cca cca ctg att-3'; 1-241: 5'-aag cag aag gec atc ctg ac-3' and 5'-cta get cga gtt atg gac gag ttg gtg gta gga-3'; 247-462: 5'-cat gcc atg gtg cgc ctg cet ctc cag gat-3' and 5'-gat atc tcg agc cgt tet tcc ac-3') and subcloned into pENTR4 as above. The T432A mutation was introduced by Pfu polymerase-based site-directed mutagenesis using the primer 5'-cgt gat atg aga cag get gtt geg gtg ggt g-3', followed by $D p n I$ digestion of the parental template. The inserts of all ENTRy vectors were verified by DNA sequencing (Microsynth). To generate expression vectors for fusion proteins, ENTRy vectors were recombined in vitro with DESTination vectors using LR Clonase recombination enzyme mix (Invitrogen). pDEST15 and pDEST17 were used to generate bacterial or rabbit reticulocyte lysate expression vectors for GST- and His -fusion proteins, respectively. pDEST10 and pDEST20 were used to generate expression vectors for $\mathrm{His}_{6}{ }^{-}$ and GST-fusion proteins, respectively, in the baculovirus/Sf9 insect cell system (Invitrogen). pcDNA3.1/nV5-DEST was used to express $\mathrm{N}$-terminal $\mathrm{V} 5$-tagged proteins in mammalian cells or in rabbit reticulocyte lysates.

\section{Generation of monoclonal antibodies}

GST-PAS fusion protein expression was induced in $E$. coli BL21-AI by $0.2 \%$ arabinose for 4 hours and affinity purified with glutathione sepharose (Amersham Biosciences, Dübendorf, Switzerland). Two mice were immunized with this antigen using standard procedures. Hybridoma cell lines were established and culture supernatant tested against the antigen, or GST alone, by ELISA and immunoblotting. Antibodies from positive hybridoma supernatants were purified using protein A agarose (EconoPac protein A cartridge, BioRad, Reinach, Switzerland) liquid chromatography. Antibody isotyping was performed using ISOstrip mouse strips (Roche Diagnostics, Mannheim, Germany).

\section{Immunoblotting}

Combined cytoplasmic and nuclear extracts of cultured cells were prepared using $0.4 \mathrm{M} \mathrm{NaCl}$ and $0.1 \% \mathrm{NP}-40$ in extraction buffer as described previously [18]. Nuclear extracts were prepared from isolated nuclei using $0.4 \mathrm{M} \mathrm{NaCl}$. Protein concentrations were determined by the Bradford method using bovine serum albumin as a standard. Immunoblotting and chemiluminescence detection was performed as described previously [19]. The following antibodies were used: mouse monoclonal antibody (mAb) Gal4 and mAb VP16 (Santa Cruz Biotechnology, Heidelberg, Germany); mAb eEF1A1 (Stressgen, Biomol, Hamburg, Germany); mAb V5 tag (Invitrogen); $\mathrm{mAb}_{\mathrm{His}}$ tag (Abcam, Cambridge, UK); rabbit polyclonal $\beta$-actin (Sigma); and secondary polyclonal goat antimouse or anti-rabbit antibodies coupled to horseradish peroxidase (Pierce, Perbio, Lausanne, Switzerland).

\section{Immunohistochemistry}

Paraffin-embedded human testis samples (tumor orchidectomy) were sectioned $(2 \mu \mathrm{m})$ and antigen retrieved by boiling the sections in $0.1 \mathrm{M}$ citrate buffer for 90 minutes. Peroxidase activity was blocked by incubating with $3 \% \mathrm{H}_{2} \mathrm{O}_{2}$

Male Germ Cell Expression of PASKIN and its Novel Target eEF1A1 and unspecific binding sites were blocked with protein-block (Dako, Hamburg, Germany). The slides were incubated with PASKIN mAb2 or mAb6, or eEF1A1 mAb, diluted 1:50 and 1:100, respectively, in $50 \mathrm{mM}$ Tris- $\mathrm{HCl} \mathrm{pH} 7.6,0.5 \mathrm{M} \mathrm{NaCl}, 0.1 \%$ Tween 20, 10\% FCS for 15 minutes. Following washing, primary antibodies were detected with the CSA enhancing system (Dako) and DAB (for PASKIN) or FastRed (for eEF1A1) substrates. PASKIN production in SF9 was detected as described above except that the Envision system (Dako) with FastRed as chromogen was employed. All slides were counterstained with hemalaun.

\section{Immunofluorescence}

Collection of human ejaculated spermatozoa was approved by the ethics committee of the University of Leipzig (approval number 067-2005). Spermatozoa were washed in PBS, streaked onto microscope slides, incubated for 5 minutes in demembranization buffer (2\% Triton-X100, 5 mM DTT, $50 \mathrm{mM}$ Tris- $\mathrm{HCl} \mathrm{pH} \mathrm{9.0)} \mathrm{and} \mathrm{fixed} \mathrm{with} 3 \%$ paraformaldehyde. The nonspecific binding sites were blocked with 3\% BSA in PBS for 30 minutes. Spermatozoa were incubated for 1 hour with PASKIN mAb2 or mAb6 diluted $1: 10$ in 3\% BSA in PBS followed by a TexasRed-coupled secondary anti-mouse antibody (Dako) or an AlexaFluor 488-coupled secondary anti-mouse antibody (Invitrogen) diluted 1:100 with 3\% BSA in PBS. HeLa cells were grown on cover slips and treated accordingly. Finally, nuclei were stained with Hoechst33258 dye for 5 minutes. After extensive washings with PBS, the slides were mounted and analyzed by fluorescence microscopy (Axioplan 2000, Carl Zeiss Vision, Mannheim, Germany) or confocal microscopy (LSM510, Carl Zeiss Vision).

\section{Cell culture, transient transfection and co- immunoprecipitation}

Human Hep3B hepatoma, HeLa cervical carcinoma and NCCIT male germ tumor (kind gift of S. Schweyer, Göttingen, Germany) cell lines were cultured in high glucose Dulbecco's modified Eagle's medium (Sigma) as described previously [20]. Transient transfection was performed with the polyethylenimine method as described before [19]. Transfection efficiency usually reached $60-80 \%$ as determined by green fluorescent protein expression (data not shown). For co-immunoprecipitation, pre-cleared cell extracts were incubated with PASKIN mAb6 covalently coupled to sepharose A beads [21]. The beads were washed with $0.5 \%$ NP-40, $50 \mathrm{mM}$ Tris-HCl pH 7.5, $250 \mathrm{mM} \mathrm{NaCl}, 5 \mathrm{mM}$ EDTA and bound proteins were analyzed by immunoblotting.

\section{Yeast two-hybrid}

A HeLa cell-derived cDNA library was screened using the PAS domain of human PASKIN as bait according to the instructions provided by the manufacturer (Clontech). Therefore, the full-length human PASKIN cDNA clone pDKFZp434O1522 [5] was digested with NcoI and SmaI and the cDNA fragment inserted into the NcoI-SmaI sites of the pAS2 vector (Clontech). Subsequently, the C-terminal part was deleted by BamHI digestion and re-ligation to obtain pAS2PAS. 
Fig. 1. Generation of two monoclonal antibodies (mAbs) specific for human PASKIN. (A) Mouse monoclonal PASKIN antibodies $\mathrm{mAb} 2$ and mAb6 were purified and used for immunoblot detection of human and two different clones of the mouse V5-tagged PAS AB fragments produced by IVTT and fulllength human $\mathrm{His}_{6}$-PASKIN expressed in Sf9 cells. The same blot was subsequently incubated with an anti-V5 tag antibody as control. (B) PASKIN wild-type or knock-out (KO) mouse and human tissue extracts were probed with mAb6 by immunoblotting. An extract from $\mathrm{Sf} 9$ cells expressing $\mathrm{His}_{6}$ PASKIN was included as positive control. The same blot was subsequently incubated with an anti- $\beta$-actin antibody as control. Note that the PASKIN mAbs react with human but not mouse PASKIN.

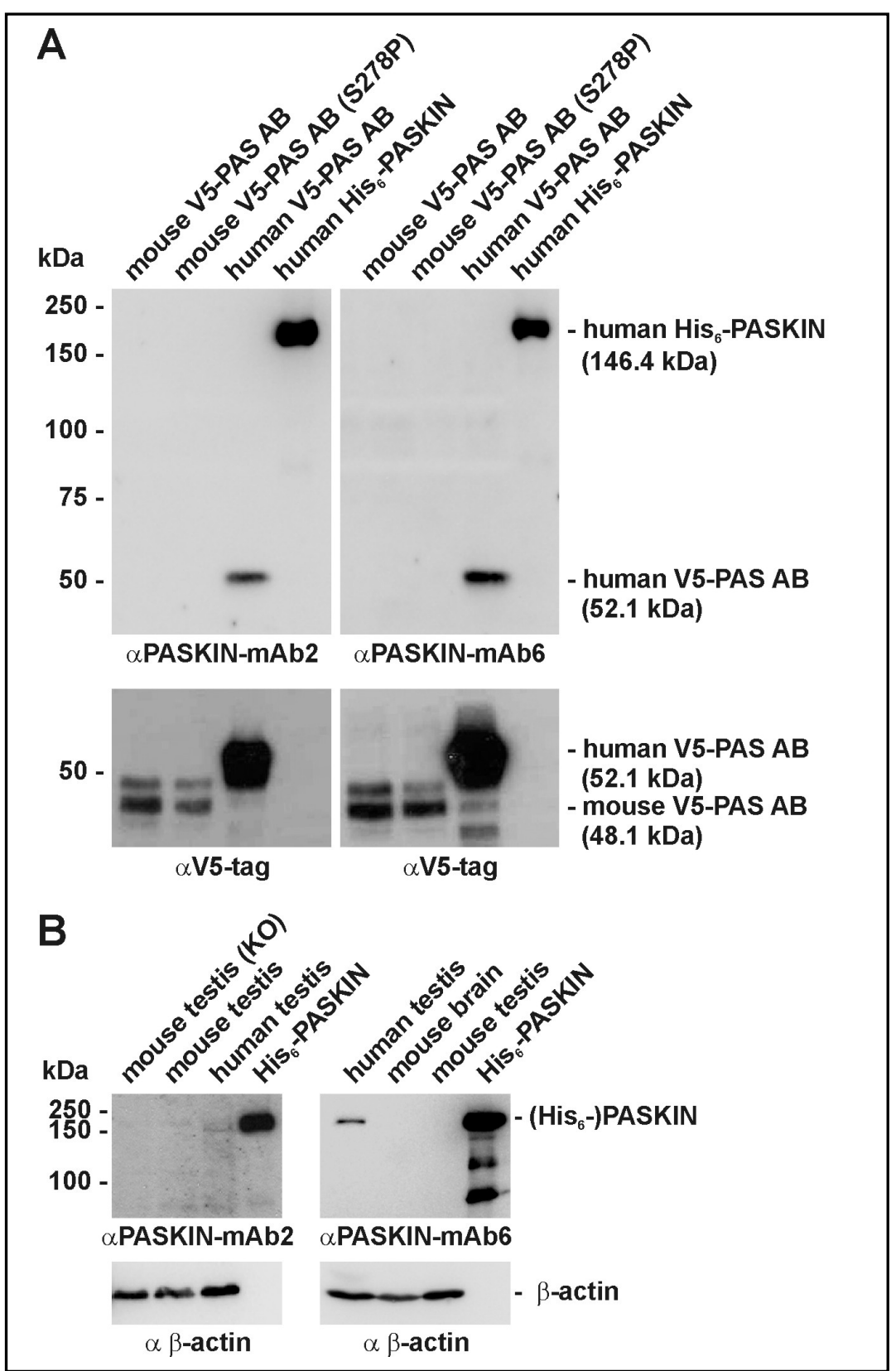

\section{Mammalian two-hybrid}

The mammalian Matchmaker vectors pM and pVP16 (Clontech) were converted to DESTination vectors by ligation of the Gateway vector conversion cassette reading frame B (Invitrogen) into the EcoRI sites (blunted with Klenow polymerase) of pM and pVP16 to obtain pMGAL4BDattb and pVP16ADattb, respectively. Mammalian expression vectors for Gal4 DNA-binding domain (BD) or VP16 activation domain (AD) fusion proteins were obtained after in vitro recombination with the corresponding ENTRy vectors. The pG5FL firefly luciferase reporter gene vector was obtained by replacing the SalI-XbaI SEAP cDNA fragment from pG5SEAP (Clontech) with the SalI-XbaI luciferase cDNA amplified by PCR (primers 5'gat ccg tcg act cta gca tgg aag acg cca aaa aca-3' and 5'-gct cta gaa tta cac ggc gat ctt tcc-3') from pGL3Basic (Promega, Madi- son, WI). Hep3B cells were transiently co-transfected with the $\mathrm{BD}$ and $\mathrm{AD}$ fusion protein vectors, the firefly luciferase reporter vector and the pRL-SV40 renilla luciferase reporter vector (Promega) to control for differences in transfection efficiency. Luciferase reporter gene activity was determined as described before [22]. Ratios between firefly and renilla luciferase activities were normalized to negative control cotransfections with the pM-53 and pVP16-CP vectors (Clontech) which were arbitrarily defined as 1 .

In vitro transcription/translation (IVTT) and GST pulldown

IVTT reactions were carried out as described by the manufacturer (Promega) using recombined DESTination vectors in the presence of ${ }^{35} \mathrm{~S}-$ Met (Hartmann Analytic, Braunschweig,

Eckhardt/Tröger/Reissmann/Katschinski/Wagner/Stengel/Paasch/ Hunziker/Borter/Barth/Schläfli/Spielmann/Stiehl/Camenisch/Wenger 
Germany). For translation assays, separate IVTT reactions $(1 \mu \mathrm{l})$, containing the pDEST17 expression vector alone, galactosidase expressing $l a c Z$ expression vector, wild-type or mutant PASKIN, were mixed with fresh reticulocyte lysate (12.5 $\mu 1)$ and $12.5 \mathrm{ng}$ renilla luciferase cRNA (Promega). Luciferase activity was determined as above. GST-tagged proteins or GST alone were expressed in E. coli BL21-AI by induction with $0.2 \%$ arabinose for 4 hours and affinity purified using glutathione sepharose columns (GSTrap FF, Amersham Biosciences) by liquid chromatography (BioLogic DuoFlow, BioRad). Pulldown experiments were performed by mixing either purified proteins or $20 \mu \mathrm{l}$ wheat germ IVTT reactions with $10 \mu \mathrm{g}$ purified GST-tagged proteins or GST alone bound to glutathione sepharose beads. After 30 minutes incubation at room temperature in bead binding buffer $(50 \mathrm{mM}$ Tris- $\mathrm{HCl} \mathrm{pH} 8.0,1 \mathrm{mM}$ EDTA, $1 \mathrm{mM}$ DTT, $150 \mathrm{mM} \mathrm{NaCl}, 0.01 \%$ NP40), beads were washed 3 times with washing buffer $(50 \mathrm{mM}$ Tris- $\mathrm{HCl} \mathrm{pH} 8.0,1$ mM EDTA, $1 \mathrm{mM}$ DTT, $150 \mathrm{mM} \mathrm{NaCl}, 0.5 \% \mathrm{NP} 40$ ), boiled in sample buffer (40 mM Tris- $\mathrm{HCl} \mathrm{pH} 6.8,1 \%$ SDS, $50 \mathrm{mM} \beta$ mercaptoethanol) for 5 minutes and the proteins separated by SDS-PAGE. Gels were stained with coomassie blue, dried and radioactively labelled proteins detected by phosphorimaging (Molecular Imager FX, BioRad).

\section{Kinase assays and mass spectrometry}

$\mathrm{His}_{6}$-PASKIN was purified from baculovirus-infected $\mathrm{Sf} 9$ insect cells using Ni-NTA agarose (Qiagen, Basel, Switzerland). His $_{6}$-PASKIN was incubated with $2 \mu \mathrm{g}$ bacterially expressed and purified GST-tagged eEF1A1 (full-length or fragments) or GST alone in $25 \mathrm{mM}$ Tris-HCl pH 8.0, $10 \mathrm{mM} \mathrm{MgCl}_{2}, 1 \mathrm{mM}$ DTT for 20 minutes in the presence of $5 \mu \mathrm{Ci}\left(\gamma^{33} \mathrm{P}\right) \mathrm{ATP}$ (Hartmann Analytic). Proteins were separated by SDS-PAGE and analyzed by phosphorimaging of the dried gels. To determine the phosphorylation site, GST-eEF1A1 was incubated with ATP and PASKIN, separated by SDS-PAGE and excised from the gel. One third of the gel band was cut into small pieces and washed twice with $100 \mu 1100 \mathrm{mM} \mathrm{NH}_{4} \mathrm{HCO}_{3}, 50 \%$ acetonitrile and once with $50 \mu \mathrm{l}$ acetonitrile. GST-eEF1A1 was digested ingel with $30 \mu \mathrm{l}$ trypsin solution (modified trypsin, Promega, 10 $\mathrm{fg} / \mu \mathrm{l}$ in $50 \mathrm{mM}$ Tris- $\mathrm{HCl} \mathrm{pH} 8.2,2 \mathrm{mM} \mathrm{CaCl}_{2}$ ) at $37^{\circ} \mathrm{C}$ over night. The supernatant was removed and the gel pieces were extracted twice with $100 \mu 10.1 \%$ TFA, 50\% acetonitrile. All three supernatants were combined in autosampler vials, dried, and dissolved in $10 \mu 10.1 \%$ formic acid for LC/ESI/MS/MS analysis run in the neutral loss mode for phosphopetides (Q-TOF Ultima API, Waters/Micromass, Manchester, UK; equipped with a capLC, Waters).

\section{Results}

Generation and characterization of monoclonal antibodies against PASKIN

In order to determine the physiological sites of expression in vivo as well as the subcellular localization of mammalian PASKIN, monoclonal antibodies (mAbs) derived against PASKIN were generated. Therefore, a

Male Germ Cell Expression of PASKIN and its Novel Target eEF1A1
GST-PAS AB fusion protein was expressed in E. coli, purified and used for the immunization of mice. mABs were purified from hybridoma cell lines which reacted with GST-PAS AB but not GST alone. Two PASKIN $\mathrm{IgG}_{2 \mathrm{a}} \mathrm{mAbs}, \mathrm{mAb} 2$ and $\mathrm{mAb} 6$, recognized in vitro transcribed and translated (IVTT) human V5-PAS AB as well as $\mathrm{His}_{6}-\mathrm{PASKIN}$ by immunoblotting (Fig. 1A). However, none of the mAbs reacted with mouse PAS AB fragments, while V5-tag antibodies readily detected the recombinant proteins (Fig. 1A), demonstrating that these mAbs do not cross-react with mouse PASKIN. In human testis extracts both mAbs detected a single band that co-migrated with recombinant $\mathrm{His}_{6}$-PASKIN isolated from baculovirus-infected Sf9 cells (predicted MW: 146.4 $\mathrm{kDa}$ ), suggesting that endogenous human PASKIN (predicted MW: $143.7 \mathrm{kDa}$ ) is either not or only slightly posttranslationally modified in the testis (shown for PASKIN mAb6 in Fig. 1B). No corresponding band could be observed in mouse organs, including testis and brain (Fig. 1B).

\section{PASKIN protein localization in germ cells of the testis}

We previously reported that the mouse Paskin gene is expressed in the testis at least 100-fold stronger than in any other organ tested [12]. As shown above, also immunoblotting revealed PASKIN protein only in the testis. Thus, PASKIN mAb2 and mAb6 were used to analyze the PASKIN protein localization in human testis by immunohistochemistry. Signals for PASKIN were obtained in the outermost layer of cells in human seminiferous tubules, corresponding to the self-replicating spermatogonia, and in spermatocytes and round spermatids (Fig. 2A and C). At higher magnifications it became apparent that apart from some cytoplasmic staining PASKIN localized to the nuclei of spermatogonia and spermatocytes with a pattern that might match the nucleoli, at least in spermatogonia (Fig. 2B and D). In ejaculated human sperm cells, PASKIN localized mainly to the midpiece of the tail and was absent in the nucleus as determined by immunofluorescence (Fig. 2E and F).

\section{Cytoplasmic and nuclear localization of PASKIN in cultured cells}

Ectopically overexpressed V5-PASKIN had originally been reported to localize to the cytosol of transfected HEK293 cells [6]. Likewise, we detected exogenously overexpressed human His $_{6}$-PASKIN exclusively in the cytoplasm of baculovirus-infected Sf9 insect cells by immunohistochemistry using PASKIN mAb6 (Fig. 3A). 
Fig. 2. Subcellular localization of PASKIN in human testis and spermatozoa. Indirect immunohistochemistry of human testis (A to D) and indirect immunofluoresence of ejaculated human sperm cells (E, F). The primary $\alpha$ PASKIN antibodies are indicated; the secondary antibodies were coupled to HRP (A to D) or Texas red (E, F).
Fig. 3. PASKIN localizes to the cytoplasm as well as to nuclear speckle-like structures in cultured HeLa cells. (A) Uninfected Sf9 cells, or Sf9 cells infected with human His $_{6}$-PASKINbaculovirus for 50 hours, were fixed, pelleted, embedded in paraffin, sectioned and analyzed by immunhistochemistry using PASKIN mAb6. (B) Immunoblotting of cytoplasmic, nuclear or total cell extracts derived from HeLa cells using PASKIN mAb6. Subsequent incubation with antibodies derived against the transcription factor Sp1 confirmed the identity of the extracts. (C) Immunoblotting of nuclear or total cell extracts derived from untransfected HeLa and NCCIT cells, or cells transfected with a V5PASKIN expression vector, using PASKIN mAb6. Subsequent detection of actin served as control for equal loading and blotting $(\mathrm{B}, \mathrm{C})$. (D) Confocal indirect immunofluorescence microscopy of untransfected HeLa cells using $\alpha$ PASKIN mAb6. Nuclei were counterstained with Hoechst33258. The optical XZ and YZ planes are indicated on the sides of the $X Y$ picture to demonstrate the intranuclear localization of PASKIN.

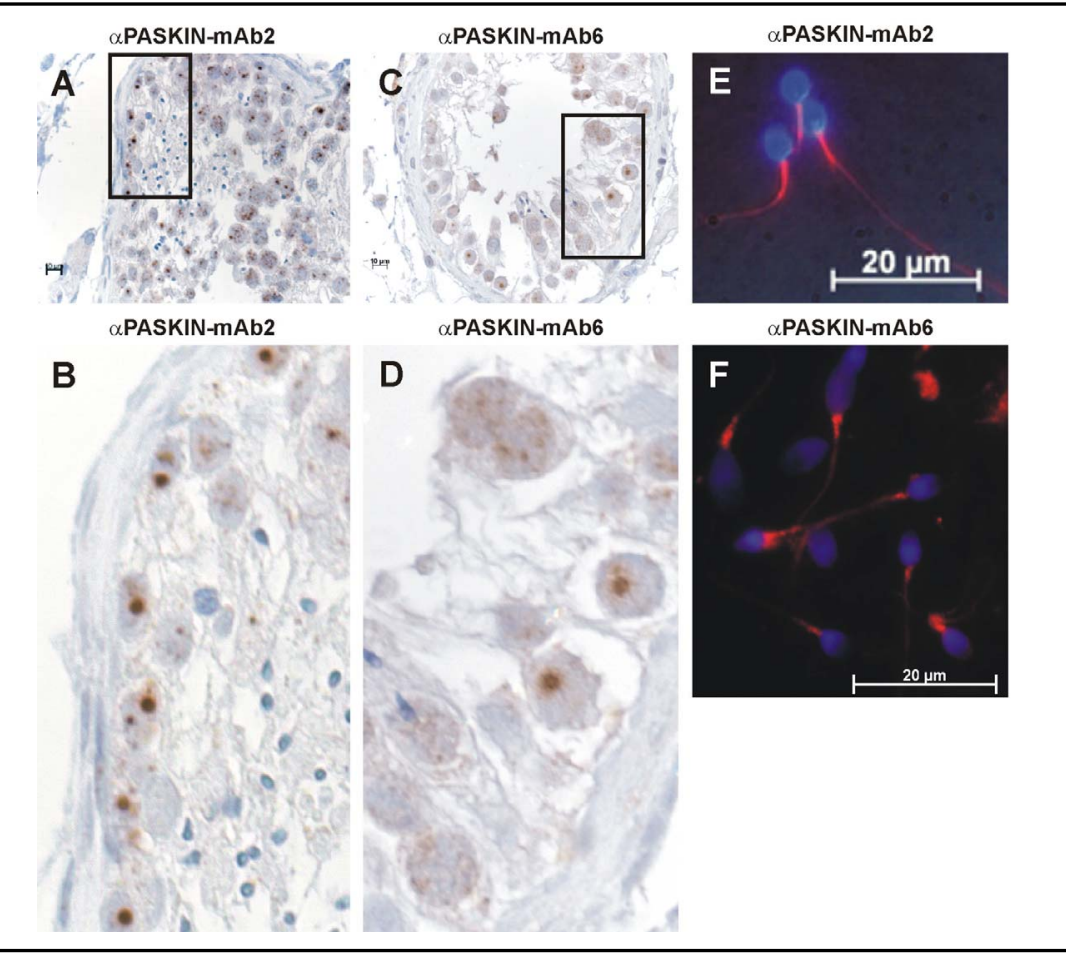

A
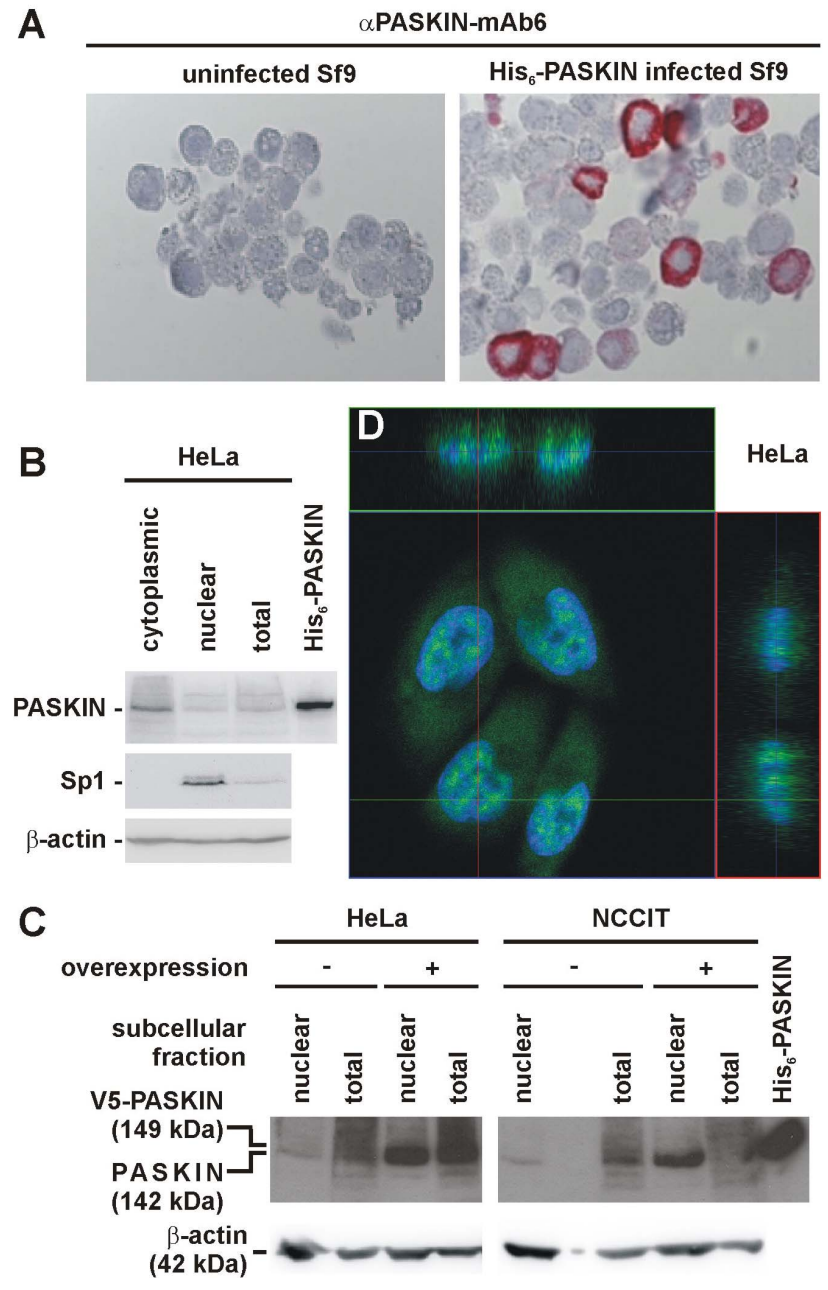
Fig. 4. PASKIN:eEF1A1 interaction in Hep3B cells. Fusion proteins between VP16-AD and full-length PASKIN (A), or the KIN domain (C), or the PAS AB domain (D), together with Gal4-BD and eEF1A1 were co-transfected into Hep3B cells together with a firefly luciferase reporter gene, containing Gal4 DNA-binding sites, and a renilla luciferase control vector. Firefly luciferase reporter gene activity was determined 24 hours later, corrected for the control renilla luciferase activity and normalized to the values obtained with a negative control transfection of a non-interacting fusion protein pair. (B), Immunoblotting of transfected Hep3B cells to confirm expression of the fusion proteins. Anti-Gal4 $\mathrm{mAb}$ detected the BD and anti-VP16 $\mathrm{mAb}$ detected the AD. An unspecific band reacting with the anti-Gal4 $\mathrm{mAb}$ served to control for equal loading. Mean values \pm SEM are shown of $7(A, C)$ or 3 (D) independent experiments performed in duplicates. $P$ values were obtained by paired t tests and considered significant if $p<0.05$.

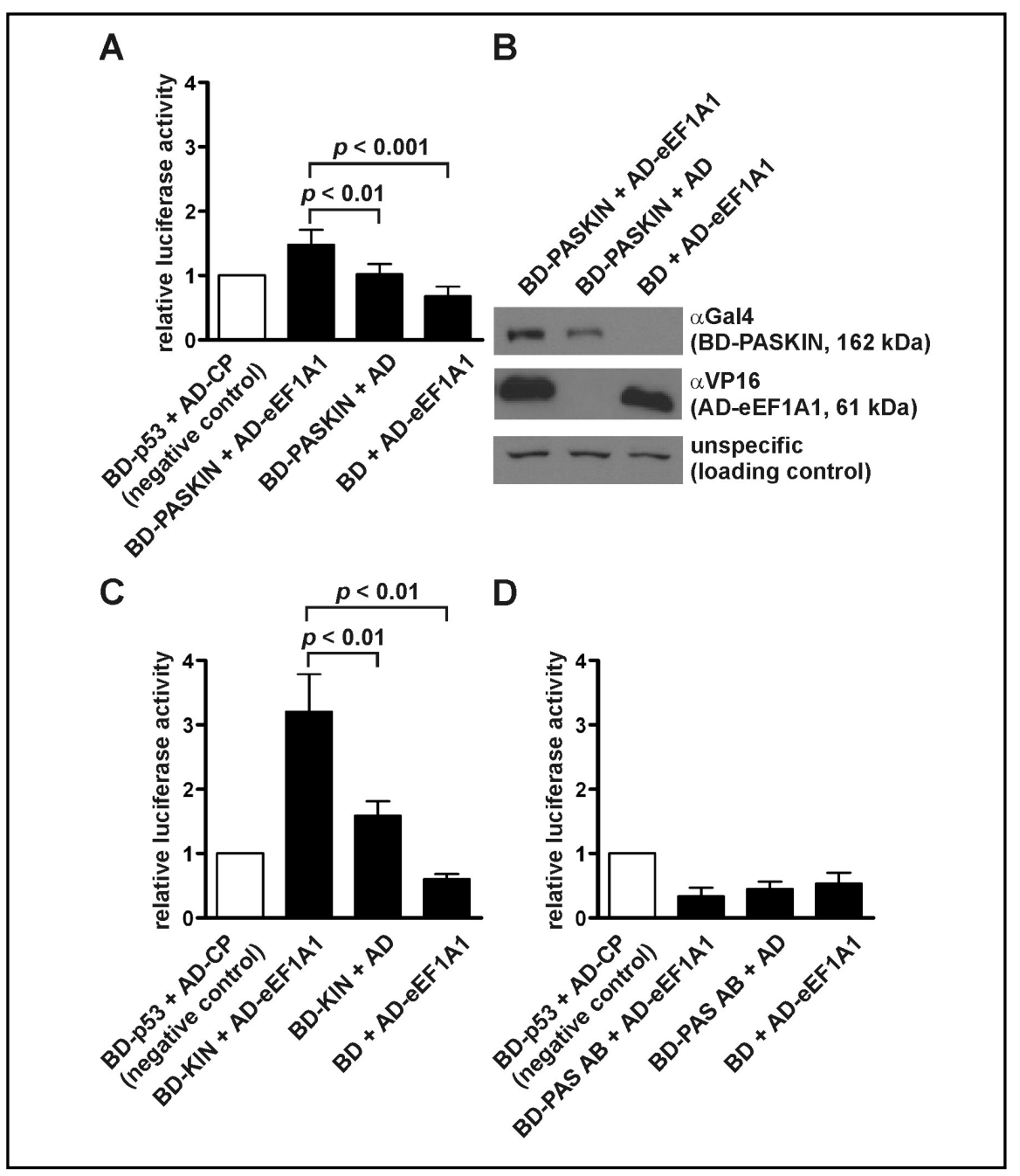

However, by biochemical separation and immunoblotting, endogenous PASKIN had also been partially detected in the nuclear fraction of HeLa cells [6]. Moreover, a recent high-throughput screen identified PASKIN in nuclear extracts derived from HeLa cells [23]. Because PASKIN showed an unexpected nuclear pattern in human testis, we analyzed subcellular PASKIN localization in HeLa human cervical carcinoma cells as well as in NCCIT human male germ tumor cells. As shown by immunoblotting with PASKIN mAb6, endogenous PASKIN could be detected in nuclear fractions derived from these cell lines in addition to the cytoplasmic fractions (Fig. 3B). Over-expression markedly increased the portion of PASKIN in the nuclear fractions (Fig. 3C). Confocal microscopy of HeLa cells using PASKIN mAb6 revealed a cytoplasmic as well as a nuclear PASKIN localization, not overlapping with areas that stained weakly with Hoechst33258 DNA stain (Fig. 3D). At present it is unclear whether the nuclear speckle-like PASKIN pattern in HeLa cells corresponds to the nucleolar-like pat-

Male Germ Cell Expression of PASKIN and its Novel Target eEF1A1 tern in spermatogonia. The cytoplasmic PASKIN staining overlapped neither with markers for the golgi apparatus (wheat germ agglutinin and concanavalin A) nor mitochondria (mitotracker) (data not shown). Taken together, these data show that PASKIN can localize to the nucleus as well as to the cytoplasm.

\section{The eukaryotic translation elongation factor eEF1A1 interacts with PASKIN}

In order to better understand the function of mammalian PASKIN, a yeast two-hybrid screen for novel proteins interacting with PASKIN was performed. eEF1A1 was identified as a prey when a region spanning the PAS A and B domains was used as bait. In order to confirm this interaction, mammalian two-hybrid experiments were performed in Hep3B human hepatoma cells co-transfected with Gal4 BD-PASKIN and VP16 AD-eEF1A1 fusion constructs. The activity of a cotransfected luciferase reporter gene construct containing five Gal4 DNA-binding sites is greatly enhanced when 
Fig. 5. PASKIN:eEF1A1 protein-protein interaction. (A) Co-immunoprecipitation of endogenous eEF1A1 with c-myctagged PASKIN expressed in HeLa cells. PASKIN mAb6 but not control antibodies co-precipitated eEF1A1 as shown by immunoblotting. (B) Purified recombinant proteins derived from $E$. coli (GST alone or GST-tagged eEF1A1, fulllength or the indicated fragments) or Sf9 insect cells (His-PASKIN) were mixed, incubated and analyzed by GST pulldown with glutathione-sepharose followed by immunoblotting using PASKIN and GST mAbs. (C, D) Protein:protein interaction between radioactively labelled fragments of PASKIN produced by IVTT and purified recombinant GST-eEF1A1 fusion protein, or GST alone, were analyzed by GST pulldown with glutathione-sepharose followed by SDS-PAGE and phosphorimaging (upper panels in $\mathrm{C}$ and D). „Input“ reflects fractions of the IVTT reactions before GST pull-down. The coomassie-stained gels are shown in the lower panels of (C) and (D) to demonstrate equal pull-down efficiency. Note that the full-length GST-eEF1A1 fusion protein is barely visible in (C).

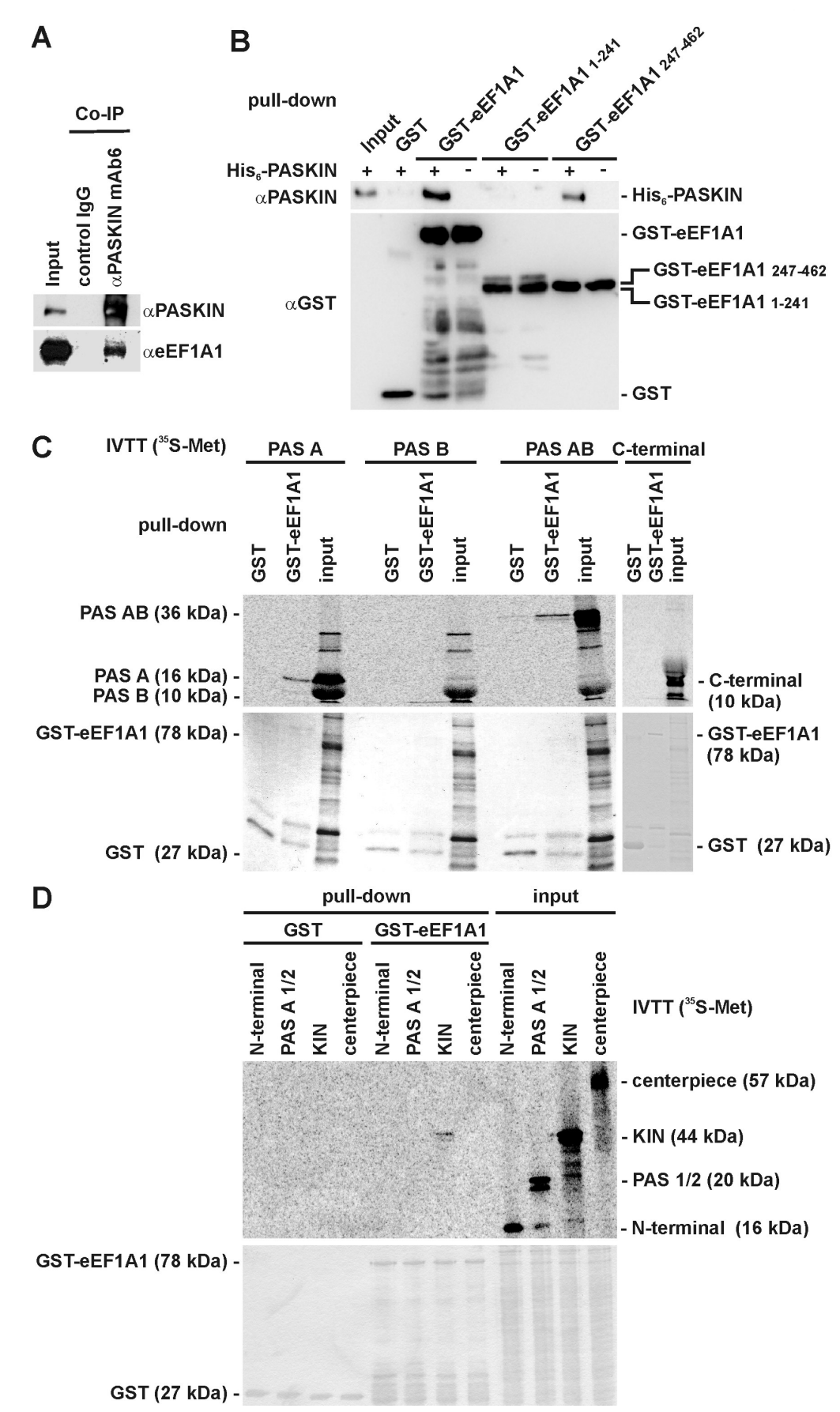

GST (27 kDa) - the $\mathrm{AD}$ comes to lie in the vicinity of the BD. As shown in Fig. 4A, luciferase expression was significantly higher when the BD-PASKIN and AD-eEF1A1 fusion constructs were co-transfected compared with cotransfection of either the BD or the AD alone. Expression of the exogenous fusion proteins was confirmed by immunoblotting with anti-Gal4 or anti-VP16 antibodies (Fig. 4B). As shown in Fig. 4C, the KIN domain of
PASKIN conferred even a stronger induction of luciferase activity than the full-length protein. Intriguingly, the two PAS domains did not stimulate luciferase expression but rather inhibited it when compared with the non-interacting negative control transfections (Fig. 4D). Thus, these results confirmed the interaction between the full-length PASKIN and eEF1A1 proteins, but showed that the PAS domains of PASKIN were inhibitory in the

Eckhardt/Tröger/Reissmann/Katschinski/Wagner/Stengel/Paasch/ Hunziker/Borter/Barth/Schläfli/Spielmann/Stiehl/Camenisch/Wenger 
mammalian eEF1A1 interaction assay whereas they were activatory in the yeast eEF1A1 interaction assay.

\section{Mapping of the PASKIN domains interacting with eEF1A1}

The interaction between endogenous eEF1A1 and PASKIN was further confirmed by coimmunoprecipitation. Because only very low amounts of endogenous PASKIN are expressed in HeLa cells (see Fig. 3B), c-myc-tagged PASKIN was transiently overexpressed and immunoprecipitated with PASKIN mAb6. As shown in Fig. 5A, mAb6 but not an isotypematched control IgG co-precipitated endogenous eEF1A1.

The PASKIN:eEF1A1 interaction was then characterized by GST pull-down experiments in vitro. Therefore, purified full-length $\mathrm{His}_{6}$-PASKIN was coprecipitated together with full-length, N-terminal or the C-terminal GST-tagged eEF1A1 using glutathione sepharose (Fig. 5B). Immunoblotting with PASKIN mAb6 detected His $_{6}$-PASKIN bound to full-length and C-terminal GST-eEF1A1 but not to N-terminal GSTeEF1A1 or GST alone (Fig. 5B, top), while GST antibodies detected all proteins on the same blot (Fig. 5B, bottom).

To map the PASKIN site(s) interacting with eEF1A1, fragments of PASKIN were transcribed and translated in wheat germ extracts and radioactively labelled by incorporation of ${ }^{35} \mathrm{~S}-\mathrm{Met}$. These fragments were tested for interaction with purified GST-eEF1A1 fusion proteins, or GST alone, by precipitation with glutathione sepharose. In this assay, the PAS A, PAS AB (Fig. 5C) as well as the KIN (Fig. 5D) domains interacted with eEF1A1, whereas the N-terminal half of PAS A, PAS B, the N- and C-termini and the piece between the PAS and KIN domains (centerpiece) did not interact with eEF1A1.

In conclusion, both the C-terminal part of the PAS A domain as well as the KIN domain independently interact with the C-terminal part of eEF1A1, providing an explanation why eEF1A1 could interact with the PAS domain of PASKIN in yeast and with the KIN domain of PASKIN in Hep3B cells.

eEF1A1 is phosphorylated by PASKIN at Thr432

We next determined whether eEF1A1 can be phosphorylated by PASKIN. Therefore, $\mathrm{His}_{6}$-PASKIN was purified from baculovirus-infected Sf9 insect cells. As expected from published results [6], $\mathrm{His}_{6}$-PASKIN autophosphorylated in the presence of ${ }^{33} \mathrm{P}-\mathrm{ATP}$, demonstrating that it was functionally active (Fig. 6A). PASKIN

Male Germ Cell Expression of PASKIN and its Novel Target eEF1A1

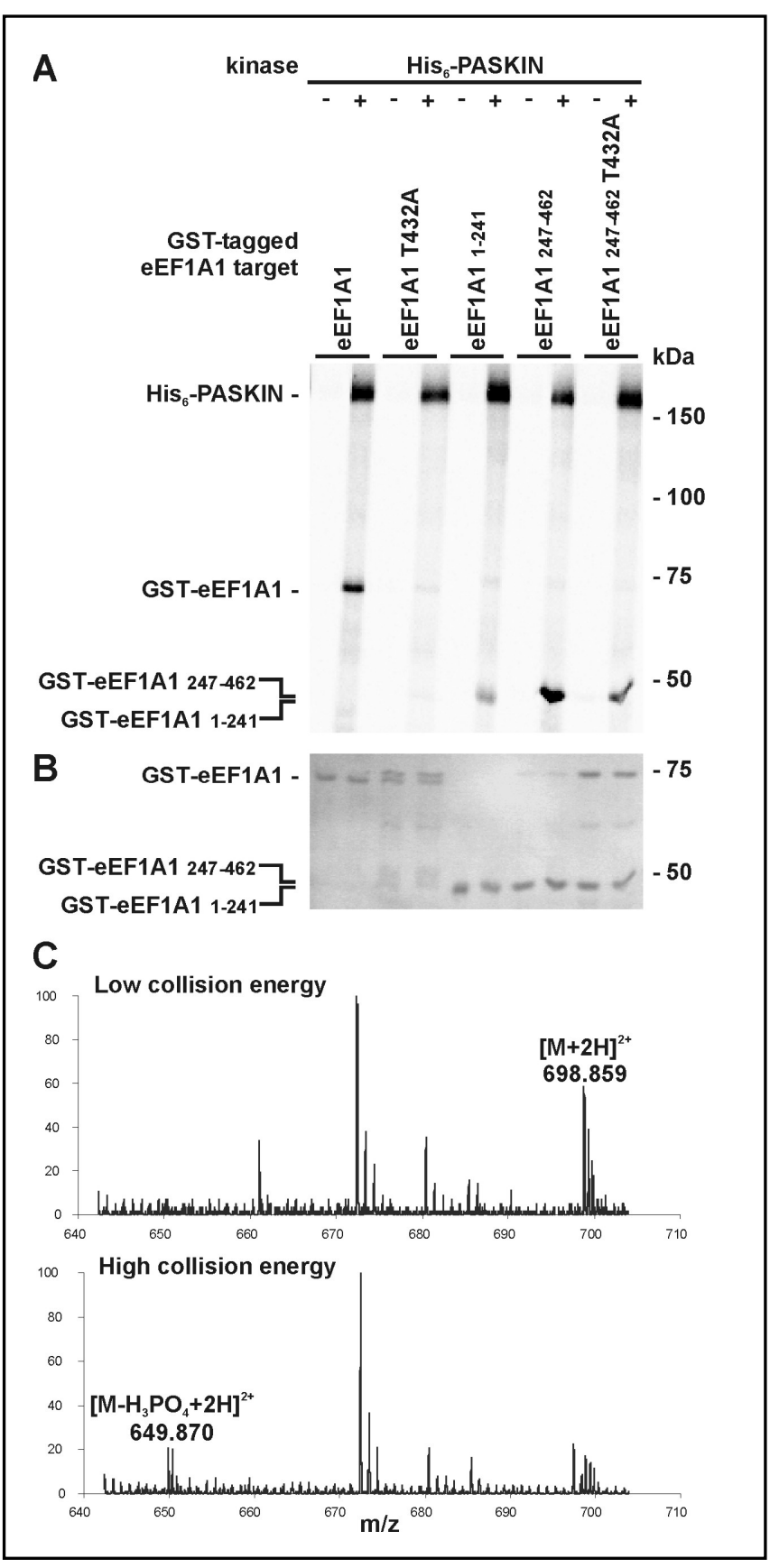

Fig. 6. PASKIN auto-phosphorylation and eEF1A1 targetphosphorylation. (A) Purified recombinant GST-eEF1A1 was in vitro phosphorylated by His-PASKIN, separated by SDSPAGE and detected by phosphorimaging. T432A mutants and fragments of eEF1A1 were included as indicated. (B) Corresponding coomassie-stained gel to indicate equimolar loading of phosphorylation target proteins. (C) Neutral loss measurement by LC/ESI/MS/MS of phospho-eEF1A1 following in-gel digestion. The mass difference of 48.989 between the measurements of the peptide DMRQTVAVGVIK at low collision energy (upper trace) and at high collision energy (lower trace) shows the presence of a phosphorylation site in this peptide. Thr432 was identified as the main PASKIN-dependent phosphorylation site in eEF1A1.

Cell Physiol Biochem 2007;20:227-240 
also phosphorylated full-length GST-eEF1A1 and GSTeEF1A1 ${ }_{247-462}$, whereas GST-eEF1A1 $1_{1-241}$ was phosphorylated to a clearly lower extent (Fig. 6A) and GST alone was not phosphorylated at all (data not shown). As shown by coomassie staining, all recombinant GST-tagged proteins were present in approx. equimolar concentrations (Fig. 6B), whereas the concentration of the kinase was too low to be detected by this technique.

To determine the phosphoacceptor site of eEF1A1, full-length GST-eEF1A1 was phosphorylated by $\mathrm{His}_{6}$ PASKIN, separated by SDS-PAGE and in-gel digested with trypsin. Separation of the fragments by liquid chromatography followed by electrospray ionization-tandem mass spectrometry in the neutral loss mode for phosphopetides identified the C-terminal peptide DMRQTVAVGVIK with Thr432 as the only phosphoacceptor site in this analysis (Fig. 6C).

To confirm the role of Thr432 it was mutated to alanine by site-directed mutagenesis. As shown in Fig. 6A, phosphorylation of full-length GST-eEF1A1T432A by $\mathrm{His}_{6}$-PASKIN was almost completely abolished. However, while GST-eEF1A1 ${ }_{247-462}$ T432A also showed impaired phosphorylation by $\mathrm{His}_{6}$-PASKIN, some residual phosphorylation of this eEF1A1 fragment was still detectable, suggesting that T432A is the major but not the only phosphoacceptor site on eEF1A1.

PASKIN increases translation efficiency in a cellfree in vitro assay

PASKIN-dependent phosphorylation of eEF1A1 suggests that PASKIN might influence translation efficiency. To test for this hypothesis, wild-type and kinaseinactive mutants of PASKIN were synthesized by IVTT in rabbit reticulocyte lysates (Fig. 7A). PASKIN was then tested for its effects on translation of a renilla luciferase cRNA in fresh rabbit reticulocyte lysates containing endogenous eEF1A1 (see Fig. 8A). While the empty IVTT expression vector, galactosidase, and kinase-inactive PASKIN T1161A and/or T1165A mutants [6] did not significantly alter protein synthesis, wild-type PASKIN increased renilla luciferase protein synthesis by $80 \%$ (Fig. 7B).

Co-localization of PASKIN and eEF1A1 in the midpiece of the sperm tail

Functional interaction between PASKIN and eEF1A1 requires a cellular co-localization. Thus, we next analyzed the subcellular localization of eEF1A1. Therefore, HeLa cells were analyzed by immunofluorescence using an eEF1A1 mAb. Immunoblotting of IVTT reticu-
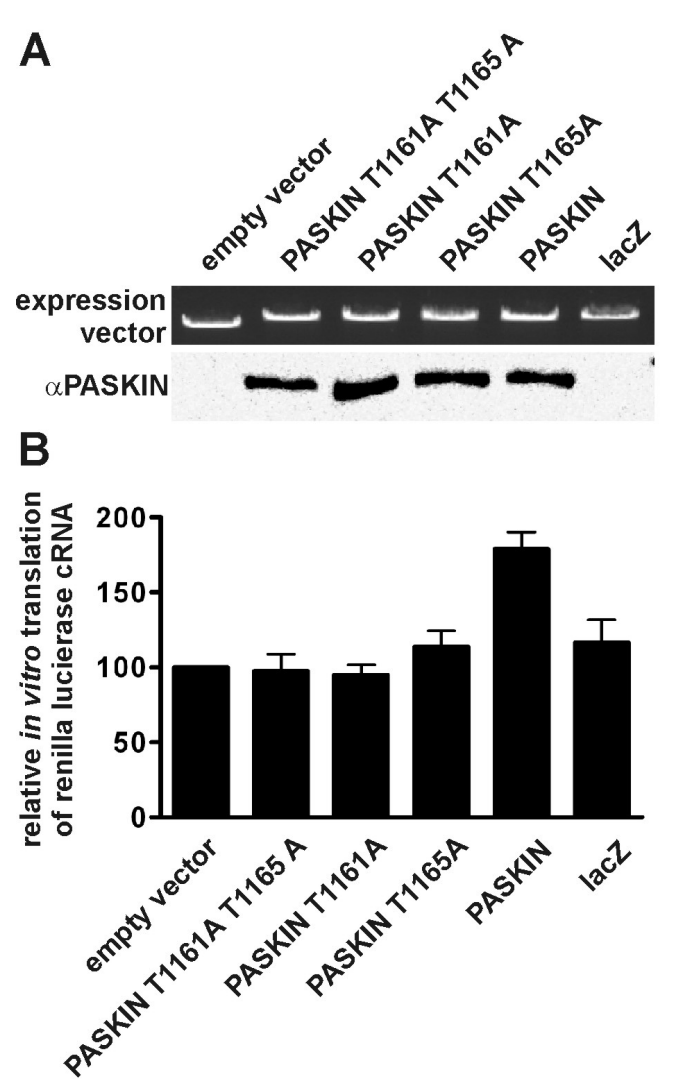

Fig. 7. PASKIN increases translation in a cell-free translation assay. (A) Wild-type PASKIN or the indicated kinase-inactive PASKIN mutants were produced by IVTT. Linearized expression vectors (agarose gel electrophoresis and ethidium bromide staining; top panel) were used to produce similar amounts of PASKIN protein (immunoblotting using PASKIN mAb6; bottom panel). (B) Translation was assayed by adding fractions of these IVTT reactions to reticulocyte lysates containing renilla luciferase cRNA. Luciferase activities were normalized to the empty vector control and are shown as mean values \pm SEM of $n=3$ independent experiments. IVTT reactions using a $l a c Z$ vector expressing galactosidase served as negative controls.

locyte extracts, containing or not containing an eEF1A1 expression vector, and of HeLa total cell extracts demonstrated the presence of eEF1A1 in HeLa cells and confirmed the specificity of the antibody (Fig. 8A). Indirect immunofluorescence with this antibody followed by an Alexa488-coupled secondary antibody localized eEF1A1 exclusively to the cytoplasm (Fig. 8B). A similar cytoplasmic localization was observed in germ cells of the human testis by immunohistochemistry (Fig. 8C). Interestingly, by indirect immunofluorescence using a Texas red-coupled secondary antibody eEF1A1 was also de-

Eckhardt/Tröger/Reissmann/Katschinski/Wagner/Stengel/Paasch/ Hunziker/Borter/Barth/Schläfli/Spielmann/Stiehl/Camenisch/Wenger 
Fig. 8. eEF1A1 and PASKIN co-localization in HeLa and sperm cells. (A) Immunoblot analysis of eEF1A1 in unprimed reticulocyte lysates, or following IVTT of an eEF1A1 expression vector, and in untransfected HeLa cells, demonstrating the specificity of the eEF1A1 mAb. (B) Confocal indirect immunofluorescence microscopy of untransfected HeLa cells using eEF1A1 primary and Alexa488-coupled secondary antibodies. (C) Immunohistochemistry of human testis using eEF1A1 mAb (red). Note that both in HeLa (B) as well as in testis (C), eEF1A1 localizes to the cytoplasm, suggesting that this is the main site of interaction with PASKIN in these cells. (D) Indirect eEF1A1 immunofluorescence microscopy of human ejaculated sperm using eEF1A1 primary and Texas red-coupled secondary antibodies. (E) Confocal indirect immunofluorescence microscopy of the midpiece of the human sperm tail using eEF1A1 or PASKIN mAb6 primary and Texas red-coupled secondary antibodies. Nuclei were counterstained with DAPI (B) or Hoechst33258 (D, E).

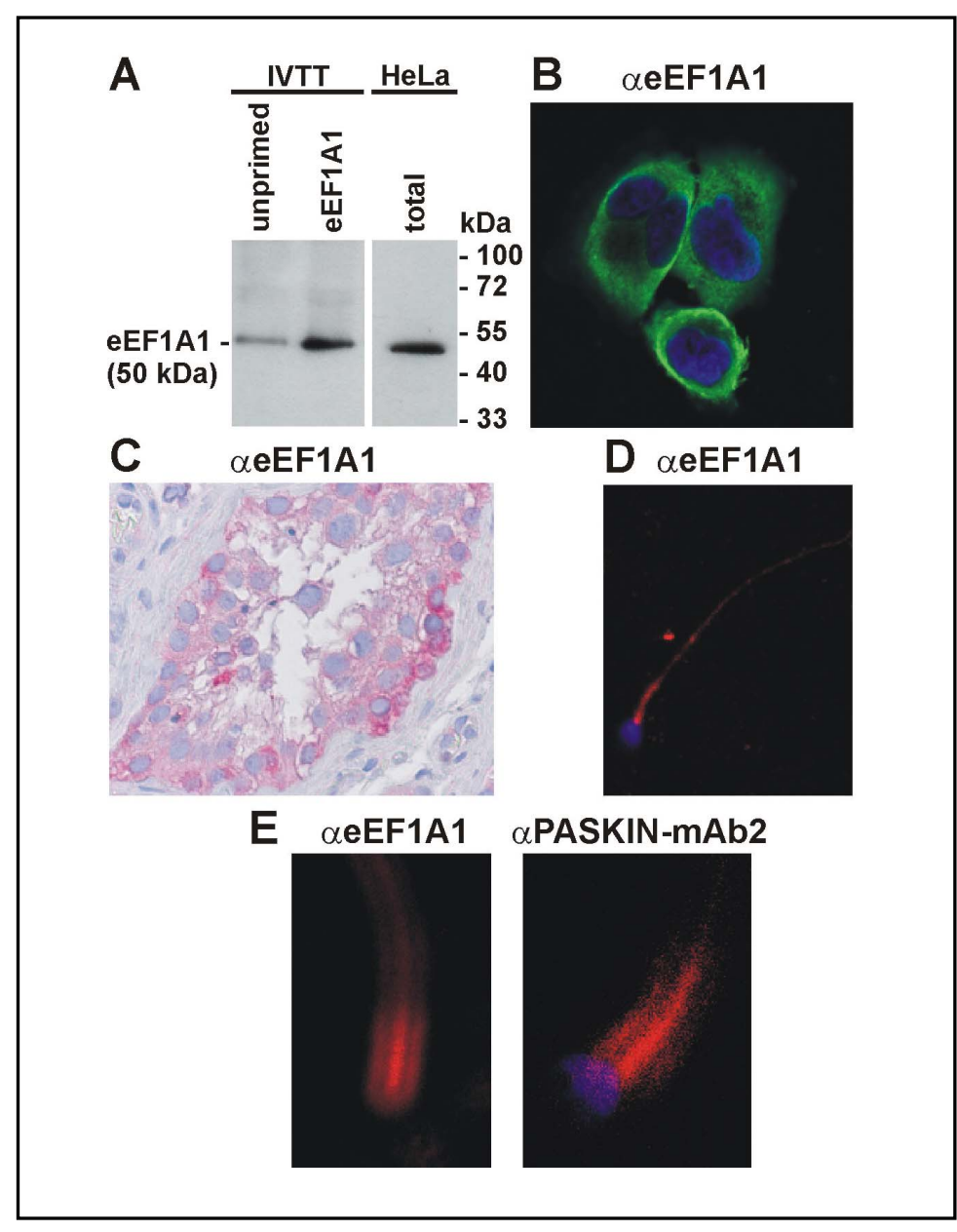

tected in the tail of ejaculated human sperm (Fig. 8D). Confocal immunofluorescence microscopy revealed a very similar pattern of eEF1A1 and PASKIN, suggesting co-localization of the two proteins in the midpiece of the sperm tail (Fig. 8E).

\section{Discussion}

We previously identified PASKIN as a gene that is ubiquitously expressed at low abundance in most mouse organs analyzed. In contrast, much higher mRNA levels were found in the testis $[5,12]$. Presumably, these low levels in somatic tissues can further be induced by changing environmental conditions, as suggested by the recent demonstration that high glucose induces PASKIN in pancreatic cells [10]. Of note, in a large-scale characterization of nuclear phosphoproteins, a PASKIN-derived phosphopeptide (Ser116) was identified in HeLa cells, suggesting a potentially regulable function for PASKIN [23]. Thus, HeLa appeared to be a valuable tool to identify PASKIN downstream targets in non-germline cells,

Male Germ Cell Expression of PASKIN and its Novel Target eEF1A1 and we identified the translation elongation factor eEF1A1 as a novel PASKIN interaction partner by yeast twohybrid screening.

We further demonstrated that the C-terminal part of eEF1A1 interacts with both the PAS A and KIN domains of PASKIN as schematically summarized in Fig. 9. Human eEF1A1 is phosphorylated by PASKIN at Thr432, suggesting that PASKIN regulates eEF1A1 function. Several other kinases are known to phosphorylate eEF1A1, including PKC, Rho-associated kinase, and S6 kinase [24-26]. Interestingly, PKC has been shown previously to phosphorylate the corresponding Thr431 PASKIN target site in mouse eEF1A1 [24], and we found PKC-dependent human eEF1A1 phosphorylation at Thr432 (data not shown). Up to date the functional consequences of this phosphorylation remain unknown. Insulin stimulation of protein synthesis involves S6 kinasedependent eEF1A1 phosphorylation [26], and here we could demonstrate that PASKIN increases protein translation in a cell-free translation assay. Thus, PASKINdependent phosphorylation of eEF1A1 might link energy metabolism with protein translation in mammalian cells 
Fig. 9. Scheme of the PASKIN:eEF1A1 interaction. Results from Figs. 4 and 5 are summarized on the right part of the picture. The eEF1A1 phosphopeptide identified following PASKIN-dependent phosphorylation is indicated. $\mathrm{Y} 2 \mathrm{H}$, yeast two-hybrid; $\mathrm{M} 2 \mathrm{H}$, mammalian two-hybrid; coIP, co-immunoprecipitation.

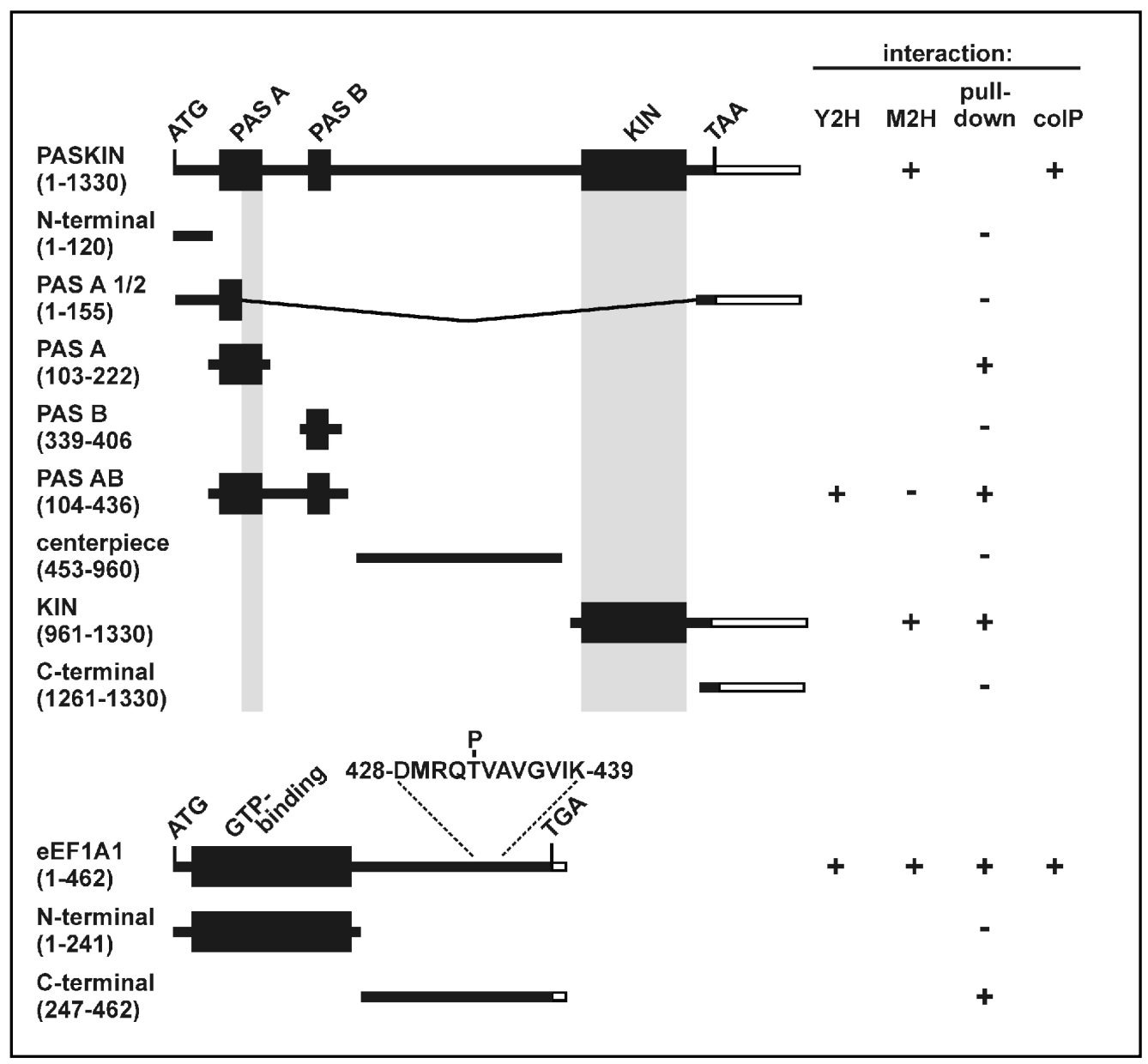

as it has been demonstrated previously for yeast [8]. However, the major site of PASKIN expression in vivo is the testis. Because no corresponding cell culture model is available, at present we can only speculate on a role for PASKIN in protein translation in male germ cells.

In addition to protein translation, PASKIN-dependent eEF1A1 phosphorylation might also have completely different consequences. In fact, eEF1A1 displays a multitude of functions unrelated to protein synthesis, including cytoskeletal organization, signal transduction, RNA synthesis, proteasomal degradation of damaged proteins, apoptosis and activation of the heat-shock transcription factor; eEF1 A1 hence is involved in major diseases such as diabetes and cancer $[15,17,27]$. We thus reasoned that the identification of the subcellular compartments which show co-localization of eEF1A1 and PASKIN might give further hints to the physiological functions of PASKIN-dependent eEF1A1 phosphorylation. In baculovirus-infected insect cells, we found PASKIN exclusively in the cytoplasm, consistent with a previous report on transiently transfected HEK293 cells [6]. Cyto- plasmic localization of endogenous PASKIN was also found in HeLa cells, suggesting a role for the PASKIN:eEF1A1 interaction in this compartment. However, in order to study the major physiological site of PASKIN expression, the testis, it was necessary to generate specific PASKIN antibodies. Unexpectedly, endogenous PASKIN showed an apparently nucleolar pattern in spermatogonia and a more speckled nuclear pattern in spermatocytes and in HeLa cells in addition to the cytoplasmic localization. A previously not recognized phosphorylation site of PASKIN (Ser116) has been identified in nuclear extracts derived from HeLa cells [23]. It is currently unknown whether phosphorylation of PASKIN Ser116 affects PASKIN subcellular localization, PASKIN kinase activity, or both.

Although eEF1A1 has also been reported to localize to the nucleus under certain circumstances [15], we detected endogenous eEF1A1 exclusively in the cytoplasm of HeLa cells and germ cells of human testis. However, there was a complete, and thus far not recognized, overlap in PASKIN and eEF1A1 expression and locali- 
zation in mature human spermatozoa. Because these cells ceased protein translation, a translation-unrelated function of PASKIN-dependent eEF1A1 phosphorylation appears to be likely. The midpiece of the sperm tail is a highly organized structure comprising cytoskeletal components, the mitochondria, and most of the remaining cytoplasmic liquid which contains several testis-specific isoforms of glycolytic enzymes as well as of the transcription factor HIF-1, another PAS domain protein [13, $28,29]$. Thus, this site is involved in the response to external stimuli by regulation of energy flux, heat-stress response and apoptosis, features that would be consistent with the known functions of PASKIN and eEF1A1. Future experiments will be required to identify the external stimuli affecting these features.

\section{Acknowledgements}

The authors wish to thank R. Fischer for the generation of monoclonal antibodies; J. Rutter, J. Nesper, S. Hägele and S. Schweyer for the generous gifts of plasmids and cells; U. Ziegler and J. Rohrer for helpful advice and discussions; and A.-K. Hellberg, B. Stier and C. Franke for excellent technical assistance. This work was supported by grants from the BMBF (NBL3 to D.M.K.), the DFG (Ka 1269/7-1 to D.M.K.), the Forschungsschwerpunkt Reproduktionsmedizin of the University of Lübeck (to K.F.W.), the Hartmann-Müller Stiftung (to R.H.W.) and the SNF (3100A0-104219 to R.H.W. and G.C.).

\section{References}

1 Ponting CP, Aravind L: PAS: a multifunctional domain family comes to light. Current Biol 1997;7:R674-R677.

2 Lowrey PL, Takahashi JS: Genetics of the mammalian circadian system: Photic entrainment, circadian pacemaker mechanisms, and posttranslational regulation. Annu Rev Genet 2000;34:533562 .

3 Mimura J, Fujii-Kuriyama Y: Functional role of $\mathrm{AhR}$ in the expression of toxic effects by TCDD. Biochim Biophys Acta 2003;1619:263-268.

4 Wenger RH, Stiehl DP, Camenisch G: Integration of oxygen signaling at the consensus HRE. Sci STKE 2005;2005:re12.

5 Hofer T, Spielmann P, Stengel P, Stier B, Katschinski DM, Desbaillets I, Gassmann M, Wenger RH: Mammalian PASKIN, a PAS-serine/threonine kinase related to bacterial oxygen sensors. Biochem Biophys Res Commun 2001;288:757764.

6 Rutter J, Michnoff CH, Harper SM, Gardner KH, McKnight SL: PAS kinase: An evolutionarily conserved PAS domain-regulated serine/threonine kinase. Proc Natl Acad Sci U S A 2001;98:89918996.
Amezcua CA, Harper SM, Rutter J, Gardner KH: Structure and interactions of PAS kinase N-terminal PAS domain: model for intramolecular kinase regulation. Structure 2002;10:1349-1361.

8 Rutter J, Probst BL, McKnight SL: Coordinate regulation of sugar flux and translation by PAS kinase. Cell 2002;111:1728.

9 Wilson WA, Skurat AV, Probst B, de PaoliRoach A, Roach PJ, Rutter J: Control of mammalian glycogen synthase by PAS kinase. Proc Natl Acad Sci U S A 2005;102:16596-16601.

10 da Silva Xavier G, Rutter J, Rutter GA: Involvement of Per-Arnt-Sim (PAS) kinase in the stimulation of preproinsulin and pancreatic duodenum homeobox 1 gene expression by glucose. Proc Natl Acad Sci U S A 2004;101:8319-8324.

11 An R, da Silva Xavier G, Hao HX, Semplici F, Rutter J, Rutter GA: Regulation by PerArnt-Sim (PAS) kinase of pancreatic duodenal homeobox-1 nuclear import in pancreatic beta-cells. Biochem Soc Trans 2006;34:791-793.
12 Katschinski DM, Marti HH, Wagner KF, Shibata J, Eckhardt K, Martin F, Depping R, Paasch U, Gassmann M, Ledermann B, Desbaillets I, Wenger RH: Targeted disruption of the mouse PAS domain serine/threonine kinase PASKIN. Mol Cell Biol 2003;23:6780-6789.

13 Wenger RH, Katschinski DM: The hypoxic testis and post-meiotic expression of PAS domain proteins. Semin Cell Dev Biol 2005; 16:547-553.

14 Borter E, Niessen M, Zuellig R, Spinas GA, Spielmann P, Camenisch G, Wenger $\mathrm{RH}$ : Glucose-stimulated insulin production in mice deficient for the PAS kinase PASKIN. Diabetes 2007;56:113-117.

15 Ejiri S: Moonlighting functions of polypeptide elongation factor 1: from actin bundling to zinc finger protein R1associated nuclear localization. Biosci Biotechnol Biochem 2002;66:1-21.

16 Browne GJ, Proud CG: Regulation of peptide-chain elongation in mammalian cells. Eur J Biochem 2002;269:5360-5368.

17 Lamberti A, Caraglia M, Longo O, Marra M, Abbruzzese A, Arcari P: The translation elongation factor $1 \mathrm{~A}$ in tumorigenesis, signal transduction and apoptosis: review article. Amino Acids 2004;26:443-448. 
18 Katschinski DM, Le L, Schindler SG, Thomas T, Voss AK, Wenger RH: Interaction of the PAS B domain with HSP90 accelerates hypoxia-inducible factor- $1 \alpha$ stabilization. Cell Physiol Biochem 2004;14:351-360.

19 Stiehl DP, Wirthner R, Köditz J, Spielmann P, Camenisch G, Wenger RH: Increased prolyl 4-hydroxylase domain proteins compensate for decreased oxygen levels. Evidence for an autoregulatory oxygen-sensing system. J Biol Chem 2006;281:23482-23491.

20 Katschinski DM, Le L, Heinrich D, Wagner KF, Hofer T, Schindler SG, Wenger RH: Heat induction of the unphosphorylated form of hypoxia-inducible factor- $1 \alpha$ is dependent on heat shock protein-90 activity. J Biol Chem 2002;277:9262-9267.

21 Harlow E, Lane D: Using antibodies. A laboratory manual. Cold Spring Harbor, NY, Cold Spring Harbor Laboratory Press, 1999.
22 Martin F, Linden T, Katschinski DM, Oehme F, Flamme I, Mukhopadhyay CK, Eckhardt K, Tröger J, Barth S, Camenisch G, Wenger RH: Copper-dependent activation of hypoxia-inducible factor (HIF)-1: implications for ceruloplasmin regulation. Blood 2005;105:4613-4619.

23 Beausoleil SA, Jedrychowski M, Schwartz D, Elias JE, Villén J, Li J, Cohn MA, Cantley LC, Gygi SP: Large-scale characterization of $\mathrm{HeLa}$ cell nuclear phosphoproteins. Proc Natl Acad Sci U S A 2004;101:12130-12135.

24 Kielbassa K, Müller HJ, Meyer HE, Marks F, Gschwendt M: Protein kinase $\mathrm{C} \delta$-specific phosphorylation of the elongation factor eEF- and an eEF-1 peptide at threonine 431. J Biol Chem 1995;270:6156-6162.

25 Izawa T, Fukata Y, Kimura T, Iwamatsu A, Dohi K, Kaibuchi K: Elongation factor-1 is a novel substrate of Rho-associated kinase. Biochem Biophys Res Commun 2000;278:72-78.
26 Chang YW, Traugh JA: Phosphorylation of elongation factor 1 and ribosomal protein S6 by multipotential S6 kinase and insulin stimulation of translational elongation. J Biol Chem 1997;272:2825228257.

27 Shamovsky I, Ivannikov M, Kandel ES, Gershon D, Nudler E: RNA-mediated response to heat shock in mammalian cells. Nature 2006;440:556-560.

28 Marti HH, Katschinski DM, Wagner KF, Schäffer L, Stier B, Wenger RH: Isoformspecific expression of hypoxia-inducible factor-1 $\alpha$ during the late stages of mouse spermiogenesis. Mol Endocrinol 2002;16:234-243.

29 Depping R, Hägele S, Wagner KF, Wiesner RJ, Camenisch G, Wenger RH, Katschinski DM: A dominant-negative isoform of hypoxia-inducible factor- $1 \alpha$ specifically expressed in human testis. Biol Reprod 2004;71:331-339. 